\title{
HUBUNGAN PENDAMPINGAN SUAMI DALAM PERSALINAN DENGAN KEMAJUAN PERSALINAN KALA I FASE AKTIF DI RB. BUNDA PUJA TEMBILAHAN
}

\author{
Dewi Erlina Asrita Sari ${ }^{1}$, Nurul Indah Sari ${ }^{2}$, Nanda Putri Zulaikha ${ }^{3}$ \\ 1,2,3 Akademi Kebidanan Husada Gemilang Tembilahan \\ Email: deasfardha@gmail.com (korespondensi)
}

\begin{abstract}
The labor is the process by which thet baby, placenta and membranes come out of the mother's uterus. Childbirth companion is a person who can do much to be able to help the mother during labor. Based on the preliminary survey, the number of mothers in RB. Bunda Puja in 2017 as many as 282 normal maternity mothers. Observation results for 1 week from 8 maternity mothers there were 6 people accompanied and 2 people who were not accompanied by their husbands or families, from 6 people who were accompanied by the birth process faster than 2 people who were not accompanied so they had a long labor. The purpose of this study was to determine the relationship of husband's assistance in labor with the progress of active phase I labor in RB. Bunda Puja Tembilahan in 2017. This type of research is analytic with Case Control design conducted on March 8 to March 10, 2018 on RB. Bunda Puja Tembilahan. The number of cases is 65 with a total sampling technique and a control group of 65 with a systematic sampling random sampling technique. Data collection tools use the Checklist sheet. Analysis of the data used is univariate and bivariate analysis with chi square test. The results of this study showed that the number of women who were accompanied by their husbands had a fast delivery as many as 43 people (66.2\%) and mothers who were not accompanied by their husbands experienced a slow delivery of 42 people (64.6\%). The results of the analysis were obtained ( $p$-value $<0.05$ ), it means that there was a relationship between the husband's assistance in labor and the progress of labor in the first phase of active phase. The medics is expected to motivate the childbirth companion in supporting the maternity mother.
\end{abstract}

Keywords: Husband's assistance, Progress of labor Kala I active phase.

\begin{abstract}
Abstrak
Persalinan adalah proses dimana bayi, plasenta dan selaput ketuban keluar dari uterus ibu. Pendamping persalinan adalah seorang yang dapat berbuat banyak untuk dapat membantu ibu saat persalinan. Berdasarkan Survey pendahuluan jumlah ibu bersalin di RB. Bunda puja pada tahun 2017 sebanyak 282 ibu bersalin normal. Hasil observasi selama 1 minggu dari 8 orang ibu bersalin ada 6 orang didamping dan 2 orang yang tidak didampingi oleh suami atau keluarganya, dari 6 orang yang didampingi proses persalinannya lebih cepat dari pada 2 orang yang tidak didampingi sehingga mengalami persalinan yang lama. Tujuan dari penelitian ini adalah untuk mengetahui Hubungan Pendampingan Suami Dalam Persalinan Dengan Kemajuan Persalinan Kala I Fase Aktif di RB. Bunda Puja Tembilahan Tahun 2017. Jenis penelitian ini analitik dengan desain Case Control yang dilakukan pada tanggal 8 Maret s/d 10 Maret 2018 di RB. Bunda Puja Tembilahan. Jumlah kasus sebanyak 65 dengan teknik total sampling dan kelompok kontrol sebanyak 65 dengan teknik pengambilan sampel secara sistematik random sampling. Alat pengumpulan data menggunakan lembar Checklist. Analisis data yang digunakan yaitu analisis univariat dan bivariat dengan uji chi square. Hasil penelitian ini menunjukan jumlah ibu bersalin yang didampingi suami mengalami persalinan yang cepat sebanyak 43 orang (66.2\%) dan ibu bersalin yang tidak didampingi suami mengalami persalinan yang lambat sebanyak 42 orang (64.6\%). Hasil analisis didapatkan $(p$-value $<0,05)$ artinya ada hubungan pendampingan suami dalam persalinan dengan kemajuan persalinan kala I Fase Aktif. Diharapkan tenaga kesehatan dapat memotivasi para pendamping persalinan dalam memberikan dukungan kepada ibu bersalin.

Kata kunci: Pendampingan Suami, Kemajuan Persalinan Kala I Fase Aktif
\end{abstract}




\section{PENDAhuluan}

Persalinan merupakan saat menegangkan dan menggugah emosi bagi ibu dan keluarga, persalinan menjadi saat yang menyakitkan dan menakutkan bagi ibu, karena itu harus dipastikan setiap ibu mendapatkan asuhan kasih sayang selama persalinan dan kelahiran. Asuhan ibu yang dimaksud berupa dukungan emosi dari suami dan anggota keluarga lainnya untuk berada disamping ibu selama proses persalinan dan kelahiran (Novi, 2012).

Pendamping persalinan adalah seorang yang dapat berbuat banyak untuk dapat membantu ibu saat persalinan. Pendamping merupakan keberadaan seseorang yang mendampingi atau terlibat langsung sebagai pemandu persalinan, yang memberi dukungan selama proses persalinan, yang memberi dukungan selama kehamilan, persalinan, dan nifas, agar proses persalinan yang dilaluinya berjalan dengan lancar dan memberi kenyamanan bagi ibu bersalin (Indrayani \& Moudy, 2013).

Keberadaan pendamping persalinan dapat menimbulkan efek positif terhadap hasil persalinan dalam arti dapat menurunkan morbiditas, mengurangi rasa sakit, persalinan yang lebih singkat, dan menurunnya persalinan dengan operasi termasuk seksio sesaria.Dukungan suami dalam proses persalinan akan memberi efek pada ibu yaitu dalam hal emosi, emosi ibu yang tenang akan menyebabkan sel-sel sarafnya mengheluarkan hormon oksitosin yang reaksinya akan menyebabkan kontraksi pada rahim pada akhir kehamilan untuk mengeluarkan bayi (Handonowati, 2009).

Kelancaran proses persalinan dapat dilihat dari lamanya proses persalinan berlangsung serta tidak mengalami hambatan dan komplikasi saat persalinan (Asrinah, 2010). Pada kenyataannya, masih banyak ibu bersalin yang mengalami ketidaklancaran proses persalinan yakni melewati garis waspada pada lembar observasi partograf. Hal ini dikarenakan ibu bersalin mengalami kecemasan yang berlebih sehingga mengganggu kontraksi yang dapat meghambat proses persalinan (Latipun, 2010).

Faktor-faktor yang mempengaruhi kelancaran persalinan diantaranya adalah: power (his, tenaga meneran), passage, passenger (janin, plasenta), psikis (salah satunya dipengaruhi oleh pendamping persalinan), posisi, tempat persalinan, dan penolong. Seorang ibu yang memasuki masa persalinan akan muncul perasaan takut tersebut akan menimbulkan stress dan memacu keluarnya hormone adrenalin yang akan mengakibatkan penyempitan pembuluh darah dan mengurangi aliran darah yang membawa oksigen ke rahim sehingga terjadi penurunan kontraksi rahim yang dapat menghambat proses persalinan. Kondisi ini akan meningkatkan angka komplikasi persalinan seperti perdarahan dan infeksi yang akan menyebabkan peningkatan angka kematian ibu (Latipun, 2010).

Beberapa wujud nyata peran suami saat istri melahirkan adalah suami harusdapat memberikan semangat dan energi yang positif. Mendampingi istri pada saat proses persalinan, suami harus memberikan katakata yang memotivasi istri menjadi semangat yang berguna pada saat proses persalinan berlangsung. Alangkah bagus lagi suami ikut langsung dalam menyaksikan persalinan, ini akan memeberikan kekuatan tersediri kepada sang istri dan istripun akan merasa dihargai oleh suami (Proberita, 2012).

Berdasarkan Survey pendahuluan jumlah ibu bersalin di RB. Bunda puja pada tahun 2017 sebanyak 282 ibu bersalin normal. Hasil observasi selama 1 minggu dari 8 orang ibu bersalin ada 6 orang didamping dan 2 orang yang tidak didampingi oleh suami atau keluarganya, dari 6 orang yang didampingi proses persalinannya lebih cepat dari pada 2 orang yang tidak didampingi sehingga mengalami persalinan yang lama.

\section{TINJAUAN PUSTAKA \\ 2.1. DEFENISI PERSALIAN \\ 2.1.1. Pengertian Persalian}

Persalinan adalah proses pengeluaran hasil konsepsi yang dapat hidup dari dalam uterus kedunia luar. Persalinan mencakup proses fisiologis yang memungkinkan serangkaian perubahan yang besar pada ibu pada ibu untuk dapat melahirkan janinnya melalui jalan lahir. Persalinan dan kelahiran normal merupakan proses pengeluaran janin yang terjadi pada kehamilan cukup bulan (37-42 minggu), lahir spontan dengan presentasi belakang kepala yang berlangsung dalam 18 jam, tanpa komplikasi baik pada ibu maupun janin (Jannah, 2015).

Persalinan adalah proses membuka dan menipisnya servik. Masa kehamilan di mulai dari konsepsi, dan janin turun ke dalam jalan lahir. Kelahiran adalah proses di mana janin dan ketuban didorong keluar melalui jalan lahir persalinan normal adalah proses pengeluaran janin yang terjadi pada kehamilan cukup bulan (37-42 minggu), lahir spontan dengan presentasi belakang kepala yang berlangsung dalam 18 jam, tanpa komplikasi baik ibu maupun janin (Indrayani\& Moudy, 2013). 


\subsubsection{Pengertian Persalian}

Sebab-sebab terjadinya persalinan sampai saat ini belum diketahui secara pasti, kemungkinan adanya banyak faktor yang saling berkaitan, sehingga pemicu persalinan menjadi multifaktor. Beberapa teori yang kompleks yang dianggap berpengaruh terhadap kejadian persalinan, yaitu hormone fetus, plasenta, strusktur uterus sirkulasi uterus, pengaruh tekanan pada saraf dan nutrisi.

Berbagai penelitian tentang permulaan persalinan berfokus pada keseimbangan kadar hormon yang merangsang kontraksi dan kadar hormone yang cenderung merelaksasikan otot-otot uterus. Perubahan rasio kadar estrogen-progesteron darah maternal meningkat waktu persalinan, meningkatkan sensitifitas uterus untuk berkontraksi. Stimulasi kontraksi uterus dilakukan oleh prostaglandin membran fetus dan oksitosin kelenjar hipofisis posterior ibu.

Estrogen dan progesterone merupakan hormone yang dominan pada saat hamil dimana hormon estrogen berpengaruh terhadap peningkatan sensitivitas otot Rahim dan memudahkan penerimaan rangsangan dariluar seperti rangsangan oksitosin, rangsangan prostaglandin, rangsangan mekanis, dan menyebabkan otot Rahim dan otot polos relaksasi. Pada masa kehamilan, kadar hormone estrogen dan progesterone berada pada kondisi yang seimbang sehingga kehamilan dapat dipertahankan. Dengan bertambahnya usia kehamilan, terjadi perubahan keseimbangan estrogen dan progesteron. Pada akhir kehamilan, kadar progesterone menurun dan kadar estrogen dalam darah ibu sangat meningkat.

Kadar estrogen merupakan akibat kenaikan sekresi corticotropin releasing hormone $(\mathrm{CRH})$ oleh plasenta yang menstimulasi hipofisis anterior fetus agar mensekresi adrenocorticotropichormone (ACTH), yang menstimulasi kelenjar adrenal fetus agar mensekresi kortisol dan Dehidroepi Androsterone (DHEA) plasenta kemudian merubah DHEA menjadi estrogen (Sulistiyawati, 2010).

\subsection{DEFENISI PERSALIAN}

\subsubsection{Passage Way}

Passage way merupakan jalan lahir dalam persalinan berkaitan keadaan segmen atas dan segmen bawah rahim pada persalinan. Segmen atas memegang peran yang aktif karena berkontraksi dan dindingnya bertambah tebal dengan majunya persalinan. Sebaliknya segmen bawah rahim memegang peran pasif dan makin tipis dengan kemajuannya persalinan karena adanya peregangan. Jalan lahir terdiri dari pelvis dan jaringan lunak serviks, dasar panggul, vagina dan introitus (bagian luar/lubang luar dari vagina). Walupun jaringan lunak terutama otot dasar panggul membantu kelahiran bayi tetapi pelvic ibu jauh lebih berperan dalam proses kelahiran. Oleh karena itu, ukuran dan bentuknya harus sesuai.

\subsubsection{Passanger}

a. Janin

Janin bergerak sepanjang jalan lahir akibat interaksi beberapa faktor, di antaranya : ukuran kepala janin, presentasi, letak, sikap dan posisi janin karena plasenta dan air air ketuban juga harus melewati jalan lahir, maka dianggap sebagai dari passenger yang menyertai janin. Namun plasenta dan air ketuban jarang menghambatv proses persalinan pada kehamilan normal. Bagian yang paling besar dank eras dari janin adalah kepala janin. Posisi dan besar kepala dapat mempengaruhi jalan persalinan.

\section{b. Tali Pusat}

Umumnya plasenta akan terbentuk lengkap pada kehamilan kira-kira 16 minggu, dimana ruang amnion telat mengisis seluruh rongga rahim. Tali pusat/cord umbillicalis disebut juga foeniculus. Pada minggu ke-5 tali pusat terbentuk tali pusat terdapat antara pusat janin dan permukaan fetal plasenta.

\section{c. Plasenta}

Selama minggu ke-3 setelah konsepsi, sel tropoblast dari villi chorionic berlanjut untuk meng-invasi desidua basalis. Saat kapiler uteri terbentuk, keadaan ini berlanjut dengan arteri endometrial yang membentuk posisi seperti spiral, ruang yang terbentuk diisi dengan darah maternal. Pada setiap 15-20 kotiledon, villi chorionik bercabang keluar dengan sistem pembuluh darah fetal yang begitu kompleks. Plasenta adalah alat yang sangat penting bagi janin kerena merupakan alat pertukaran zat antara ibu dan anak dan sebaliknya.

\section{d. Air Ketuban}

Volume air ketuban pada kehamilan cukup bulan kira-kira 1000-1500 cc. air ketuban berwarna putih keruh, berbau amis dan berasa manis. Reaksinya agak alkalis atau netral, dengan berat jenis 1,008. Komposisinya terdiri atas $90 \%$ air, sisanya albumin, urea, kreatinin, sel-sel epitel, rambut lanugo, verniks caseosa dan garam an-norganik. Kadar protein kirakira 2,6\%g/l terutama albumin. Cavum amnion menerima cairan dengan difusi 
dari darah maternal. Fetus menelan cairan tersebut dengan mengalirkannya ke dalam dank ke luar paru fetal. Urine fetus juga mengalir masuk ke dalam cairan ini yang akan mempertinggi volume cairan amnion (hidramnion) dihubungkan dengan malformasi gastrointestinal dan malformasi lainnya.

\subsubsection{Power}

Power adalah kekuatan yang mendorong janin keluar (power) terdiri dari:

a. His

His merupakan kontraksi otot rahim pada persalinan yang terdiri dari kontraksi otot dinding perut, kontraksi diafragma pelvis atau kekuatan mengejan dan kontraksi ligamentum rotundum.

b. Tenaga pengejan '

Power atau tenaga yang mendorong janin keluar, kontraksi uterus karena otot-otot polos rahim bekerja dengan baik dan sempurna dengan sifat-sifat:

a) Kontraksi simetris.

b) Fundus dominan.

c) Relaksi.

d) Involunter:terjadi di luar kehendak.

e) Intermitten: terjadi secara berkala (berselang-seling).

f) Terasa sakit.

g) Terkoordinasi.

h) Kadang dapat dipengaruhi dan luar secara fisik, kimia dan psikis.

Perubahan-perubahan akibat his:

a. Pada uterus dan serviks

Uterus teraba keras/padat karena kontraksi. Tekanan hidrostatis air ketuban dan tekanan intrauterine aik serta menyebabkan serviks menjadi mendatar (effacement) dan terbuka (dilatasi).

b. Pada ibu

Rasa nyeri karena iskemia uterus dan kontraksi uterus. Juga ada kenaikan nadi dan tekanan darah.

\section{c. Pada janin}

Pertukaran oksigen pada sirkulasi uteroplasenter kurang, maka timbul hipoksia janin. Denyut jantung janin melambat (bradikardi) dan kurang jelas didengar karena adanya iskemia fisiologis. Jika benar-benar terjadi hipoksia yang agak lama, misalnya pada kontraksi tetanik, maka terjadi gawat janin asfiksia dengan denyut jantung janin di atas 160 per menit, tidak teratur (Indrayani \& Moudy, 2016).

\subsubsection{Position}

Posisi ibu mempengaruhi adaptasi

anatomi dan fisiologi persalinan. Posisi tegak memberi sejumlah keuntungan. Mengubah posisi membuat rasa letih hilang, memberi rasa nyaman dan melancarkan sirkulasi darah. Posisi tegak meliputi posisi berdiri, berjalan, duduk, jongkok. Posisi tegak memungkinkan gaya gravitasi untuk penurunan bagian terendah janin. Kontraksi uterus lebih kuat dan lebih efisien untuk membantu penipisan dan dilatasi serviks sehingga persalinan lebih cepat. Posisi tegak dapat mengurangi insidensi penekanan tali pusat (Indrayani \& Moudy, 2016).

\subsubsection{Psychology}

Pisikologi adalah respon psikologi ibu terhadap proses persalinan. Faktor psikologi sosial terdiri dari persiapan fisik maupun mental melahirkan, nilai dan kepercayaan sosiobudaya, pengalaman melahirkan sebelumnya, harapan terhadap persalinan, kesiapan melahirkan, tingkat pendidikan, dukungan orang yang bermakna dan status emosional. Kepercayaan beragama dan spiritual dapat mempengaruhi kepercayaan ibu tentang penyebab nyeri, penyembuhan dan pemeliharaan penyedia asuhan layanan kesehatan. Kepercayaan tersebut dapat menjadi sumber kekuatan dan rasa nyaman ibu atau dalam keadaan krisis. Faktor psikososial dan spiritual ibu merupakan faktor yang paling utama (Indrayani \& Moudy, 2016).

\subsubsection{Psychology}

Pisikologi adalah respon psikologi ibu terhadap proses persalinan. Faktor psikologi sosial terdiri dari persiapan fisik maupun mental melahirkan, nilai dan kepercayaan sosiobudaya, pengalaman melahirkan sebelumnya, harapan terhadap persalinan, kesiapan melahirkan, tingkat pendidikan, dukungan orang yang bermakna dan status emosional. Kepercayaan beragama dan spiritual dapat mempengaruhi kepercayaan ibu tentang penyebab nyeri, penyembuhan dan pemeliharaan penyedia asuhan layanan kesehatan. Kepercayaan tersebut dapat menjadi sumber kekuatan dan rasa nyaman ibu atau dalam keadaan krisis. Faktor psikososial dan spiritual ibu merupakan faktor yang paling utama (Indrayani \& Moudy, 2016).

\subsection{KEMAJUAN PERSALINAN}

Kemajuan persalinan ditandai dengan meningkatnya effecement dan dilatasi cerviks yang diketahui melalui pemeriksaan dalam. Pemeriksaan dilakukan setiap 4 jam sekali atau apabila ada indikasi tertentu (seperti menunjukkan adanya tanda gejala kala II). 
Kala I pada primigravida berlangsung 12 jam sedangkan pada multigravida 8 jam. Berdasarkan Kurve Friedman, diperhitungkan pembukaan primigravida $1 \mathrm{~cm} / \mathrm{jam}$ dan pembukaan multigravda $2 \mathrm{~cm}$. lama kala II pada primigravida yaitu 50 menit dan multigravida 30 menit (Takiya, 2012).

\subsection{Menilai Kemajuan Persalinan}

Persalinan merupakan saat yang menegangkan dan dapat mengubah emosi ibu atau bahkan dapat menimbulkan penyulit bagi ibu maupun janinnya, maka upaya untuk mengatasi hal tersebut digunakan partograf sebagai pemantau kemajuan persalinan.

\subsection{Tahapan Persalinan}

Persalinan dibagi menjadi 4 tahap, pada kala I serviks membuka dari 1 sampai $10 \mathrm{~cm}$. kala I dinamakan kala pembukaan. Kala II disebut juga dengan kala pengeluaran, oleh karena itu kekuatan his dan kekuatan mnengedan, janin didorong keluar sampai lahir. Dalam kala III atau disebut juga dengan kala uri, plasenta terlepas dari dinding uterus dan dilahirkan. Kala IV mulai dari lahirnya plasenta sampai 2 jam kemudian. Dalam kala tersebut diobservasi apakah terjadi perdarahan post partum.

\subsubsection{Kala I}

Kala I adalah kala pembukaan yang berlangsung antara pembukaan satu sampai lengkap, pada permulaan his, kala pembukaan berlangsung tidak begitu kuat sehingga ibu masih dapat berjalan-jalan. Klinis dapat ditanyakan mulai terjadi partus jika timbul his dan ibu mengeluarkan lendir yang bercampur dengan darah (bloody show). Lendir yang bersemadarah ini berasal dari lendir kanalis servikalis karena serviks mulai membuka atau mendatar. Sedangkan darah berasal dari pembuluh-pembuluh darah kapiler yang berada disekitar kanalis servikalis tersebut pecah. Proses ini berlangsung kurang lebih 18-24 jam, yang terbagi menjadi 2 fase, yaitu laten dan fase aktif. Berdasarkan kurve friedman, diperhitungkan pembukaan pada primigravida $1 \mathrm{~cm} / \mathrm{jam}$ dan $2 \mathrm{~cm} / \mathrm{jam}$ pada multigravida. Dengan perhitungan tersebut maka waktu pembukaan lengkap dapat diperkirakan. Kala I terdiri dari dua fase (Sumarah dkk, 2011) :

\section{a. Fase Laten}

Dimulai sejak awal berkontraksi yang menyebabkan penipisan dan pembukaan serviks secara bertahap. Berlangsung hingga serviks membuka kurang $4 \mathrm{~cm}$. pada umumnya, fase laten berlangsung hampir atau hingga 8 jam. Kontraksi mulai teratur masih diantara 20-30 detik.

b. Fase Aktif

Frekuensi dan lama kontraksi uterus akan meningkat secara bertahap (kontraksi dianggap adekuat/memadai jika terjadi tiga kali atau lebih dalam waktu 10 menit, dan berlangsung selama 40 detik atau lebih).

\subsubsection{Kala II}

Kala II atau kala pengeluaran adalah priode persalinan yang dimulai dari pembukaan lengkap sampai bayi lahir.

a. His semakin kuat dengan interval dua sampai toga menit, dengan durasi 50 sampai 100 detik.

b. Menjelang akhir kala I ketuban pecah yang ditandai dengan pengeluaran cairan secara mendadak.

c. Ketuban pecah pafa pembukaan mendekati lengkap diikuti keinginan mengejan, karena tertekan fleksus frakenhouser.

d. Kedua kekuatan, his dan mengejan lebih mendorong kepala bayi sehingga terjadi, kepala membuka pintu, subocciput bertindak sebagai hipogmolion berturut-turut lahir ubunubun besar, dahi, hidung dan muka, sehingga seluruh kepala lahir.

e. Kepala lahir dikuti dengan putaran paksi luar, yaitu penyesuaian kepala dan punggung.

f. Setelah terjadinya putaran paksi luar berlangsung, maka persalinan pun ditolong.

g. Lamanya kala II untuk primigravida 50 menit dan multigravida 20 menit.

\subsubsection{Kala III}

Kala III atau kala uri adalah priode persalinan yang di mulai dari lahirnya bayi sampai dengan lahirnya plasenta. Lama kala uri 8,5 menit dan pelepasan plasenta hanya memakan waktu 2-3 menit.

\subsubsection{Kala IV}

Kala IV merupakan masa 2 jam setelah plasenta lahir. Dalam klinik, atas pertimbangan-pertimbangan praktis masih di akui adanya kala IV persalinan meskipun masa setelah plasenta lahir adalah dimulainya masa nifas, meningkat pada masa ini yang sering timbul perdarahan (Indrayani\& Moudy, 2013).

\subsection{Menghadirkan persalinan}

Pengalaman melahirkan dapat meningkatkan kepercayaan diri dan memori positif. Oleh karena itu, dukungan dari 
pendamping persalinan dapat mempengaruhi ibu bersalin karena dapat berbuat banyak untuk membantu pada saat proses persalinan. Pendamping tersebut dapat memberikan dorongan, motivasi, membantu menciptakan suasana yang nyaman dalam ruangan bersalin, melaporkan gejala-gejala yang terjadi pada ibu kepada bidan dan membantu ibu untuk megatasi rasa ketidaknyamanan fisik.

\subsubsection{Definisi Pendamping}

Pendamping persalinan adalah seorang yang dapat berbuat banyak untuk dapat membantu ibu saat proses persalinan. Pendamping merupakan keberadaan seseorang yang mendampingi atau terlibat langsung sebagai pemandu persalinan, yang memberi dukungan selama kehamilan, persalinan, dan nifas, agar proses persalinan yang dilaluinya berjalan dengan lancer dan memberi kenyamanan bagi ibu bersalin.

Kehadiran seorang pendamping persalinan mempunyai arti yang besar karena dapat berbuat banyak untuk membantu ibu saat proses persalinan, pendamping tersebut akan memberi dorongan dan keyakinan pada ibu selama persalinan, membantu memberikan suasana yang nyaman dalam ruang bersalinan, membantu mengawasi ibu, membantu melaporkan gejala-gejala atau sakit pada bidan atau dokter, dan membantu ibu mengatasi rasa tidak nyaman fisik.

\subsubsection{Tujuan Pendamping Persalinan}

Dalam proses persalinan sangat dibutuhkan pendamping persalinan, untuk memberikan dukungan dan bantuan kepada ibu saat persalinan serta dapat memberikan perhatian, rasa aman, nyaman, nyaman, semangat, menentramkan hati ibu, mengurangi ketegangan ibu atau memperbaiki status emosional sehingga dapat mempersingkat proses persalinan.

\subsubsection{Siapa yang mendampingi}

Hal-hal yang harus diperhatikan untuk menjadi pendamping persalinan adalah orang-orang yang berarti bagi ibu bersalin yang dapat berbuat banyak membantu ibu saat persalinan. Hal yang wajar apabila pendamping gugup dan sangat sulit menyaksikan orang yang disayangi merasa kesakitam saat persalinan. Kesempatan yang diberikan kepada pendamping persalinan untuk mendampingi ibu selama bersalin dapat memperetarat hubungan emosional mereka karena sudah bersama-sama melalui sebuah peristiwa penting dihidup mereka.

\subsubsection{Manfaat Pendamping}

Ada beberapa manfaat apabila pendamping persalinan menemani ibu saat bersalin yaitu memberikan rasa ketenangan, penguat psikis pada ibu saat kontraksi uterus, selalu ada bila dibutuhkan, kedekatan emosional suami dan istri bertambah, suami akan lebih menghargai istrikarena melihat pengorbanan istri saat persalinan akan dapat lebih menghargai istrinya dan menjaga perilakunya.

\subsubsection{Tindakan pendamping saat persalinan}

Tindakan pendamping persalinan adalah semua tindakaan yang dilakukan oleh setiap pendamping persalinan, untuk membantu meningkatkan motivasi ibu dalam menyelesaikan proses persalinan.Bentuk tindakan yang dapat dilakukan seorang pendamping adalah sebagai berikut: Tetap menghibur dan mendukung ibu, memberi makanan dan minuman pada ibu, membimbing ibu mengejan dan bernafas panjang saat dimulai mengejan, melakukan pijatan punggung untuk meredakan sakit pada punggung ibu, posisikan sesuai dengan permintaannya, menggenggam tangannya, dll (Indrayani \& Moudy, 2016).

\section{KERANGKA KONSEP, DEFINISI OPERASIONAL, DAN HIPOTESIS}

\subsection{KERANGKA KONSEP}

Kerangka Konseptual merupakan dasar pemikiran pada penelitian yang dirumuskan dari fakta-fakta, observasi. Kerangka konsep ini menjadi patokan untuk melakukan penelitian

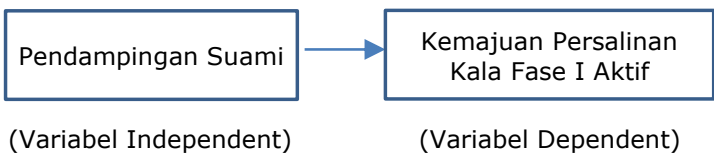

Gambar 1. Kerangka Konsep

\subsection{DEFINISI OPERASIONAL}

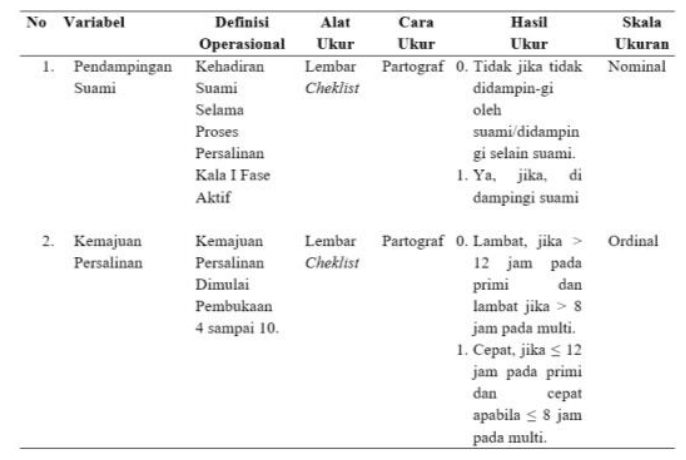

\subsection{HIPOTESIS}


Hipotesis adalah pernyataan yang belum terujikan secara empirik dengan demikian, dikaitkan dengan masalah penelitian, hipotesis merupakan jawaban sementara terhadap permasalahan yang diajukan, yang kebenaran jawabannya akan dibuktikan secara empirik dengan penelitian yang akan dilakukan (Budiman, 2008).

$\mathrm{Ha}$ : Ada hubungan pendampingan suami dalam persalinan dengan kemajuan persalinan Kala I Fase Aktif di RB. Bunda Puja.

\section{METODE PENELITIAN}

\subsection{Desain Penelitian}

Jenis Penelitian yang digunakan adalah studi analitik yaitu penelitian atau penelaahan hubungan antara dua variabel pada suatu situasi atau sekelompok subyek untuk melihat hubungan antara gejala satu dengan gejala yang lain, atau variabel satu dengan variabel yang lain, dengan pendekatan case control. Studi kasus kontrol membandingkan antara kelompok kasus, yaitu kemajuan persalinan kala I Fase aktif, dan kelompok kontrol adalah pendampingan suami.

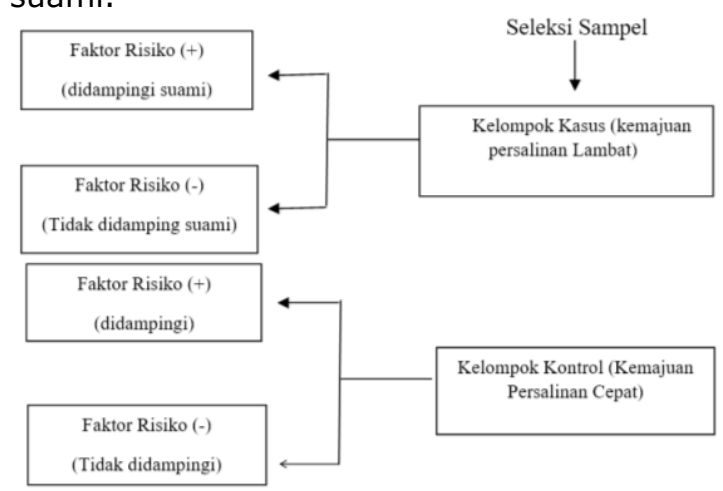

Gambar 2. Desain Penelitian

\section{PEMBAHASAN}

Berdasarkan hasil penelitian yang dilakukan di RB. Bunda Puja Tembilahan, menunjukan bahwa ibu bersalin yang mengalami persalinan lambat sebagian besar persalinannya tidak diadampingi oleh suami sebanyak 42 orang (64.6\%) dan ibu bersalin yang mengalami persalinan cepat sebagian besar persalinannya didampingi oleh suami sebanyak 43 orang (66.2\%). Hasil uji statistik diperoleh nilai $\mathrm{P}$-value $=0,000$ yang artinya ada hubungan antara pendampingan Suami dalam persalinan dengan kemajuan persalinan kala I Fase Aktif. Nilai OR3.569 yang artinya ibu bersalin yang tidak didampingi suami beresiko 3.569 kali mengalami persalinan yang lambat dibandingkan ibu bersalin yang didampingi suami.
Hasil penelitian ini sejalan dengan penelitian Thalibatun Nisa dalam penelitiannya tahun 2014 yang berjudul "Hubungan Peran Suami Terhadap Proses Kelancaran Persalinan Normal Pada Ibu Primipara Di Rumah Sakit Umun Daerah Pidie Jaya"denganv-value 0,000 yaitudidapatkan hasil bahwa ada hubungan pada pendamping suami terhadap kemajuan persalinan karena setiap ibu bersalin mendapat dukungan fisik yang baik, sebesar $76 \%$ mengalami kelancaran proses persalinan dan $24 \%$ mengalami proses persalinan yang tidak lancar..

Pendamping persalinan adalah seorang yang dapat berbuat banyak untuk dapat membantu ibu saat proses persalinan. Pendamping merupakan keberadaan seseorang yang mendampingi atau terlibat langsung sebagai pemandu persalinan, yang memberi dukungan selama kehamilan, persalinan, dan nifas, agar proses persalinan yang dilaluinya berjalan dengan lancer dan memberi kenyamanan bagi ibu bersalin (Indrayani \& Moudy, 2013)

Keberadaan pendamping persalinan dapat menimbulkan efek positif terhadap hasil persalinan dalam arti dapat menurunkan morbiditas, mengurangi rasa sakit, persalinan yang lebih singkat, dan menurunnya persalinan dengan operasi termasuk seksio sesaria. Dukungan suami dalam proses persalinan akan memberi efek pada ibu yaitu dalam hal emosi, emosi ibu yang tenang akan memberi efek pada sel-sel sarafnya yang dapat mengeluarkan hormon oksitosin yang reaksinya akan menyebabkan kontraksi rahim pada akhir kehamilan untuk mengeluarkan bayi (Handonowati, 2009).

Pengalaman melahirkan dapat meningkatkan kepercayaan diri dan memori positif. Oleh karena itu, dukungan dari pendamping persalinan dapat mempengaruhi ibu bersalin karena dapat berbuat banyak untuk membantu pada saat proses persalinan. Pendamping tersebut dapat memberikan dorongan, motivasi, membantu menciptakan suasana yang nyaman dalam ruangan bersalin, melaporkan gejala-gejala yang terjadi pada ibu kepada bidan dan membantu ibu untuk megatasi rasa ketidaknyamanan fisik (Indrayani \& Moudy, 2013).

Pendamping persalinan khususnya orang yang terdekat dengan ibu biasanya dapat membuat ibu lebih tenang dan mengurangi kecemasan ibu karena merasa dilindungi oleh orang terdekatnya. Dengan adanya pendamping persalinan, ibu dapat menceritakan apa yang ibu rasakan sehingga pendamping persalinan dapat memberikan 
dukungan seperti mendengarkan keluhan ibu, memijat punggung ibu, memberikan ibu minum atau makan sehingga dapat mengurangi stres atau kecemasaan saat proses persalinan.

\section{KESIMPULAN}

Berdasarkan hasil dan pembahasan maka dapat dikesimpulkan yaitu:

a. Distribusi frekuensi pendampingan suami pada kelompok kasus sebagian besar tidak didampingi sebanyak 42 orang (64.6\%) dan pada kelompok kontrol sebagian besar didampingi sebanyak 43 orang $(66.2 \%)$.

b. Ada hubungan antara pendampingan suami dalam persalinan dengan kemajuan persalinan kala I fase aktif di RB. Bunda Puja Tahun 2017 dengan pvalue 0,000 yang berarti ada hubungan antara pendampingann suami dalam persalinan dengan kemajuan kala I fase aktif di RB. Bunda Puja dengan nilai OR 3.569 yang artinya ibu bersalin yang tidak didampingi suami berisiko 3.569 kali mengalami kemajuan persalinan yang lambat dibandingkan ibu bersalin yang didampingi suami.

\section{Daftar Pustaka}

[1] Asrinah, 2010.Asuhan Kebidanan Masa Persalinan. Yogyakarta :Graha IImu.

[2] Budiman, Chandra. 2008. Metodologi Penelitian Kesehatan, Palembang: EGC

[3] Handonowati, 2009, Pengaruh Pendamping suami pada persalinan kala I Multidravida di RSUD Daerah Sunandi. Diakses tanggal 20 juni 2018 http://blogindonesia.com/blog-archive12132-382(2010). Pengertian suami.

[4] Hidayat, Aziz Alimul, 2008. Metode Penelitian Kebidanan Teknik Analisis Data, Surabaya: Salemba Medika

[5] , 2010. Metode penelitian kebidanan teknik analisa data, Surabaya: SalembaMedika

[6] 2014. Metode Penelitian Kebidanan Dan Teknik Analisa Data.Jakarta: SalembaMedika

[7] Indrayani,\&Moudy. 2013. Asuhan Persalinan dan Bayi Baru Lahir, Jakarta: TIM

[8] 2016. Asuhan Persalinan dan Bayi Baru Lahir, Tanggerang: TIM

[9] Jannah, Nurul, 2015. Askeb II Persalinan Berbasis Kompetensi. Jakarta: EGC

[10] JNPK, 2008. Asuhan Persalinan Normal, Jakarta

[11] Latipun, 2010. Psikologi Konseling. Diakses pada tanggal 6 Juli 2018
Website : www. cdc.gov/pendamping persalinan/training/glossary.

[12] Nisa, Thalibatun, 2014. Hubungan Peran suami terhadap proses kelancaran persalinan normal pada ibu primipara di rumah sakit umum daerah pidie jaya. Diakses tgl 26 juni 2018 http://blogindonesia.co.id/blognisa_per an-suami-dalampersalinan.

[13] Novi, 2012. Hubungan Peran Suami Sebagai Pendamping Dalam Proses Persalinan Dengan Kemajuan Persalinan Kala II di RSU PKU Muhammadiah Bantul. Diakses tanggal 20 juni 2018 http:www.blog-peran-suami-sebagaipendamping-12.

[14] Proberita, 2012. Hubungan antara Peran Suami Dengan Kesiapan Ibu Hamil Trimester III Dalam Menghadapi Persalinan Di RB. Rahayu Ungaran Kabupaten Semarang. Diakses tanggal 20 juni 2018 http: www.proberita.com/technology/kesehat an/peran-suami-saat-istri melahirkan.html.

[15] RB.Bunda Puja Tembilahan (2017) Rekam Medik Ibu Bersalin.

[16] Rosita, 2017.Hubungan Dukungan Suami Terhadap Proses Kala II Persalinan Pada Ibu Primipara Di Wilayah Kerja Puskesmas Kassi-Kassi Makasar, diakses tanggal 20 Januari 2018 JIKKHC Vol. 01/No.02/Juni/2017.

[17] Saryono, 2008. Metodologi Penelitian Kesehatan, Yogyakarta: Mitra Cendikia

[18] Sulistyawati, Ari, dkk. 2010. Asuhan Kebidanan Pada Ibu Bersalin, Jakarta: Salemba Medika.

[19] Sumarah, dkk. 2009. Perawatan ibu bersalin, Asuhan Kebidanan pada Ibu bersalin, Jakarta: Salemba Medika 